\title{
PENGARUH MODEL PEMBELAJARAN INKUIRI TERBIMBING TERHADAP HASIL BELAJAR KOGNITIF PESERTA DIDIK
}

\author{
Sumarni S ${ }^{1)}$, Bimo Budi Santoso ${ }^{2)}$, Achmad Rante Suparman ${ }^{3)}$ \\ ${ }^{1,2,3}$ Universitas Papua Manokwari \\ Jl. Gunung Salju Amban Manokwari Papua Barat \\ E-mail: arnhysumarni@gmail.com ${ }^{1)}$, achmad.unipa@gmail.com ${ }^{3)}$
}

\begin{abstract}
Abstrak. Penelitian pengaruh model pembelajaran inkuiri terbimbung dari pencapaian kognitif siswa di SMA Negeri 01 Manokwari (studi pada pokok bahasan kelarutan dan hasil kali kelarutan) yang bertujuan untuk mengetahui apakah ada perbedaan yang signifikan antara model pembelajaran inkuiri terbimbing dan model pembelajaran konvensional hasil belajar kognitif siswa dan untuk mengukur persen pengaruh dari kedua model yang digunakan. Penelitian ini menggunakan desain eksperimen metode penelitian kuasi dengan desain pretest posttest. Teknik pengambilan data sampel dilakukan dengan purposive sampling.Instrument yang digunakan untuk mengukur hasil belajar kognitif siswa adalah test essay.Analisis data digunakan adalah analisis deskriptif dan inferensial menggunakan software SPSS 22. Hasil penelitian menunjukkan bahwa ada perbedaan hasil belajar kognitif, model pembelajaran inkuiri terbimbing lebih baik dari model pembelajaran konvensional dengan persen pengaruh $29,49 \%$.
\end{abstract}

Kata Kunci: inkuiri terbimbing, hasil belajar kognitif

\begin{abstract}
Study the effect of inquiry learning model guided of the cognitive achievement of students in SMA Negeri 01 Manokwari (studies on the subject solubility and solubility product) which aims to determine whether there is a significant difference between the learning model of guided inquiry and conventional learning model of cognitive achievement of students and to measure the percent effect of both models was carried out. This study uses research method quasy experimental design with pretest posttest design. Mechanical sampling was done by purposive sampling. Instrument used to measure cognitive achievement of students is a test essay. Analysis of the data used is descriptive analysis and inferensial using the software SPSS 22. The results showed that there were differences in the results of a cognitive learning which the guided inquiry learning model is better than the conventional learning model with the effect of 29,49 percent.
\end{abstract}

Keywords: guided inquiry, student's cognitive 


\section{PENDAHULUAN}

Mutu pendidikan ini menyangkut pada setiap jenjang pendidikan, salah satunya adalah Sekolah Menengah Atas. Upaya peningkatan mutu pendidikan dapat dimulai dengan memperbaiki proses pembelajaran yang kurang sesuai dalam proses belajar mengajar di dalam kelas. Proses belajar mengajar pada masa ini bukanlah proses belajar mengajar yang berpusat pada guru sebagai pendidik. Proses pembelajaran yang demikian akan menempatkan guru sebagai pusat dalam pembelajaran, peserta didik akan kurang aktif dan hanya menerima materi yang diberikan oleh guru.

Suasana belajar dan pembelajaran itu diarahkan agar peserta didik dapat mengembangkan potensi dirinya, ini berarti proses pendidikan itu harus berorientasi kepada siswa (student active learning). Pendidikan adalah upaya pengembangan potensi anak didik. Dengan demikian, anak harus dipandang sebagai organisme yang sedang berkembang dan memiliki potensi.Tugas pendidikan adalah mengembangkan potensi yang dimiliki anak didik, bukan menjejalkan materi pelajaran atau memaksa agar anak dapat menghafal data dan fakta (Sanjaya, 2013).

SMA Negeri 01 Manokwari merupakan salah satu sekolah yang turut bertugas meningkatkan mutu pendidikan. Sekolah ini adalah salah satu sekolah unggulan di kota Manokwari, Papua Barat. Namun, proses pendidikan yang berlaku di sekolah tersebut masih berorientasi pada guru. Proses pendidikan yang demikian menyebabkan peserta didik lebih cenderung bergantung pada guru. Sehingga, peserta didik kurang terlibat aktif dalam proses pembelajaran.

Pemilihan model pembelajaran yang kurang tepat juga mempengaruhi hasil belajar peserta didik.Model pembelajaran konvensional yang umumnya digunakan adalah model pembelajaran yang hanya melibatkan metode pembelajaran ceramah, penugasan dan diskusi.Metode penugasan yang digunakan guru adalah penugasan yang hanya langsung diberikan pada peserta didik dari Lembar Kerja Siswa (LKS) yang ada pada peserta didik. Guru kurang menuntun peserta didik dalam menyelesaikan soal-soal khususnya pada soal hitungan, sehingga peserta didik hanya mengacu pada contoh soal yang ada pada buku LKS tersebut. Selain itu, dalam proses pembelajaran ini guru cenderung berfokus pada peserta didik yang aktif dan mampu.

Model pembelajaran konvensional tersebut dirasa kurang efektif jika diterapkan dalam pelajaran kimia, khususnya pada pokok bahasan hitungan dan pemahaman konsep. Hasil belajar pada pokok bahasan Ksp pada tahun sebelumnya cukup rendah dan tidak sesuai dengan target Kriteria Ketuntasan Minimal (KKM) yang ditetapkan oleh sekolah yaitu 70. Pemilihan model pembelajaran yang tepat dengan kondisi peserta didik menjadi salah satu faktor penunjang dalam peningkatan hasil belajar peserta didik.

Model pembelajaran inkuiri terbimbing merupakan salah satu model pembelajaran yang tepat diterapkan pada kondisi kelas yang kemampuan peserta didiknya bervariasi.Model pembelajaran inkuiri terbimbing (guided inquiry) adalah model pembelajaran yang berpusat pada 
peserta didik, peserta didik juga dilatih mengembangkan kemampuan berpikir, peserta didik dilatih berpikir kritis.Selain itu, dapat membangkitkan gairah belajar pada peserta didik.

Pembelajaran inkuiri terbimbing diterapkan agar para peserta didik bebas mengembangkan konsep yang mereka pelajari.Peserta didik diberi kesempatan untuk memecahkan masalah yang mereka hadapi secara individu atau berkelompok, di dalam kelas peserta didik dilatih untuk berinteraksi dengan kawan sebayanya untuk saling bertukar informasi. Tujuan penelitian ini adalah untuk mengetahui ada tidaknya perbedaan yang signifikan antara model pembelajaran inkuiri terbimbing dan model pembelajaran konvensional terhadap hasil belajar kognitif peserta didik di SMA Negeri 01 Manokwari studi

Variabel penelitian dalam penelitian ini ada 2 yaitu variabel Bebas (independen) dan variabel terikat (dependen)..Pada penelitian ini populasi yang digunakan ialah semua peserta didik kelas XI IPA di SMA Negeri 01 Manokwari pada Tahun Ajaran 2015/2016. Sampel yang digunakan pada penelitian ini adalah kelas XI MIA 5 dan kelas XI MIA 7 di SMA Negeri 01 Manokwari dengan menggunakan teknik pengambilan porpusive sampling.

Teknik pengumpulan data pada penelitian ini terbagi menjadi 2 yaitu dengan melalui teknik nontest meliputi observasi, dan wawancara (interview).Sedangkan, teknik yang ke-2 adalah dengan menggunakan teknik tes.Teknik tes yang digunakan adalah teknik tes formatif yaitu tes hasil belajar melalui pretest dan posttest. pada pokok bahasan kelarutan dan hasil kali kelarutan serta untuk mengetahui persen pengaruh penggunaan model pembelajaran inkuiri terbimbingterhadap hasil belajar kognitif peserta didik di SMA Negeri 01 Manokwari.

\section{METODE PENELITIAN}

Penelitian ini merupakan penelitian quasi eksperiment dengan desain eksperimen PretestPosttest grup. Desain tersebut dapat dilihat pada tabel berikut ini:

Tabel 1. Desain Penelitian

\begin{tabular}{|c|c|c|c|c|}
\hline & Grup & Pretest & $\begin{array}{l}\text { Variabel } \\
\text { Terikat }\end{array}$ & Posttest \\
\hline (R) & Eksperimen & $\mathrm{Y}_{1}$ & $\mathrm{X}$ & $\mathrm{Y}_{2}$ \\
\hline (R) & Kontrol & $\mathrm{Y}_{1}$ & - & $\mathrm{Y}_{2}$ \\
\hline
\end{tabular}

Penelitian ini merupakan penelitian quasi eksperiment yang menggunakan dua sampel yang independent. Adapun teknik analisis data yang digunakan pada penelitian ini ada dua macam, yaitu teknik analisis deskriptif dan teknik analisis inferensial.Teknik analisis deskriptif digunakan untuk mendeskripsikan skor hasil belajar kognitif peserta didik pada kelas eksperimen dan kelas kontrol. Teknik analisis inferensial digunakan untuk menguji hipotesis penelitian.Sebelum melakukan analisis statistik inferensial, maka sebagai uji prasyarat dilakukan uji normalitas dan uji homogenitas dengan menggunakan SPSS 22.Pada penelitian ini juga dilakukan uji standar gain dan menghitung persen pengaruh. Uji standar gain bertujuan untuk mengetahui tingkat klasifikasi efektifitas model pembelajaran inkuiri terbimbing dan model pembelajaran 
konvensional. Gain adalah selisih antara nilai posttest dan pretest, gain menunjukkan peningkatan pemahaman atau penguasaan materi setelah pembelajaran yang dilakukan oleh guru. Hipotesis yang akan diuji dengan uji kesamaan dua rata-rata adalah sebagai berikut:

$\mathrm{H}_{0}: \mu_{1}=\mu_{2}$,

$\mathrm{H}_{1}: \mu_{1} \neq \mu_{2}$,

Dimana :

$\mathrm{H}_{0} \quad$ : Tidak terdapat perbedaan yang signifikan dalam penggunaan model Inkuiri Terbimbing terhadap hasil belajar kognitif pada pokok bahasanKelarutan dan Hasil Kali Kelarutan.

$\mathrm{H}_{1}$ : Terdapat perbedaan yang signifikan dalam penggunaan model inkuiri terbimbing terhadap hasil belajar kognitif pada pokok bahasanKelarutan dan Hasil Kali Kelarutan.

$\mu_{1}$ : Rata-rata hasil belajar kognitif kelompok eksperimen

$\mu_{2}$ : Rata-rata hasil belajar kognitif kelompok kontrol

Kriteria Pengujian : $\quad$ Jika $\quad$ sig $\geq \alpha$ $(0,025)$, maka $\mathrm{H}_{0}$ diterima
Jika $\operatorname{sig}<\alpha$

$(0,025)$, maka $\mathrm{H}_{0}$ ditolak

\section{HASIL DAN PEMBAHASAN}

Hasil belajar diperoleh melalui instrument penelitian berupa tes.Sebelum menerapkan pembelajaran dengan menggunakan model pembelajaran inkuiri terbimbing (kelas eksperimen) dan pembelajaran konvensional (kelas kontrol). Kedua kelas masing-masing diberikan pretest. Setelah masing-masing kelas melakukan proses belajar mengajar dengan perlakuaan yang berbeda, setelah itu pada masing-masing kelas diberikan posttest yang digunakan untuk mengukur sejauh mana peningkatan hasil belajar peserta didik. Hasil analisis data dihitung dengan bantuan Software SPSS 22.Hasil analisis data hasil belajar kognitif peserta didik pada kedua kelas dapat dilihat pada Tabel 2 dan Tabel 3.

Tabel 2 Statistik Deskriptif Pretest Hasil Belajar Kognitif Peserta Didik

\begin{tabular}{lrr}
\hline \multicolumn{1}{c}{ Statistik } & Pretest Eksperimen & Pretest Kontrol \\
\hline Mean & 7,3636 & 5,4706 \\
Median & 7,0000 & 5,0000 \\
Standar Deviation & 3,85534 & 3,03750 \\
Minimum & 0 & 0 \\
Maximum & 15,00 & 15,00 \\
Range & 15,00 & 15,00 \\
\hline
\end{tabular}

Tabel 3 Statistik Deskriptif Posttest Hasil Belajar Kognitif Peserta Didik

\begin{tabular}{lrr}
\hline \multicolumn{1}{c}{ Statistik } & Posttest Eksperimen & Posttest Kontrol \\
\hline Mean & 53,5455 & 34,1176 \\
Median & 50,00 & 27,50 \\
Standar Deviation & 29,55619 & 19,51963 \\
Minimum & 10,00 & 5,00 \\
Maximum & 98,00 & 75,00 \\
Range & 88,00 & 70,00 \\
\hline
\end{tabular}


Berdasarkan perolehan nilai dari Tabel 3 diatas dapat dilihat bahwa nilai rata-rata dan nilai tertinggi dari tes hasil belajar kognitif peserta didik pada kelas eksperimen yang menggunakan model pembelajaran inkuiri terbimbing lebih tinggi dibanding rata-rata dan nilai tertinggi dari tes hasil belajar kognitif peserta didik kelas kontrol yang menggunakan model pembelajaran konvensional. Hal ini menyatakan bahwa model pembelajaran inkuiri terbimbing memberikan pengaruh pengetahuan dan pemahaman peserta didik tentang Kelarutan dan Hasil Kali Kelarutan yang diajarkan.

Uji normalitas yang digunakan dalam pengolahan data pretest dan posttest dari kelas eksperimen dan kelas kontrol dengan taraf signifikan 0,05 dengan kriteria pengujian data sampel berdistribusi normal jika sig $>0,05$. Uji normalitas menggunakan bantuan Software SPSS 22 dapat dilihat hasil pengujian tersebut pada Tabel 4 dan Tabel 5 dibawah ini.

Tabel 4 Uji Normalitas Pretest Kelas Eksperimen dan Kelas Kontrol

\begin{tabular}{ccccc}
\hline & \multirow{2}{*}{ Model } & \multicolumn{3}{c}{ Kolmogrov Smirnov } \\
\cline { 3 - 5 } & & Statistic & Df & Sig. \\
\hline Hasil & Eksperimen & 0,126 & 33 & $0,200^{*}$ \\
Belajar & Kontrol & 0,138 & 34 & 0,101 \\
\hline
\end{tabular}

Tabel 5 Uji Normalitas Posttest Kelas Eksperimen dan Kelas Kontrol

\begin{tabular}{ccccc}
\hline & Model & \multicolumn{3}{c}{ Kolmogrov Smirnov } \\
\cline { 3 - 5 } & & Statistic & Df & Sig. \\
\hline Hasil & Eksperimen & 0,131 & 33 & 0,161 \\
Belajar & Kontrol & 0,180 & 34 & 0,007 \\
\hline
\end{tabular}

Berdasarkan Tabel 4 dan Tabel 5, uji normalitas dihitung dengan menggunakan Kolmogrov-smirnov diperoleh nilai signifikan pada pretest sebesar $0,200^{*}$ pada kelas eksperimen dan 0,101 pada kelas kontrol kedua nilai pretest ini berada diatas 0,05 . Hal ini menunjukkan bahwa kelas eksperimen dan kelas kontrol berdistribusi normal.Sedangkan, nilai signifikan yang diperoleh pada posttest sebesar 0,161 pada kelas eksperimen dan 0,007 pada kelas kontrol.Berdasarkan nilai signifikan yang diperoleh hal tersebut menunjukkan bahwa kelas eksperimen berdistribusi normal sedangkan kelas kontrol tidak berdistribusi normal.

Uji homogenitas dilakukan untuk mengetahui homogen atau tidaknya varian data dari sampel yang diambil. Dari data pretest dan posttest kedua kelas yang telah diperoleh dengan menggunakan bantuan Software SPSS 22 dapat dilihat pada Tabel 6 dan Tabel 7. 
Tabel 6 Uji Homogenitas Pretest Kelas Eksperimen dan Kelas Kontrol

\begin{tabular}{clrrrr}
\hline & & $\begin{array}{c}\text { Levene } \\
\text { Statistic }\end{array}$ & df1 & df2 & Sig. \\
\hline Hasil & Berdasarkan nilai rata-rata & 1,364 & 1 & 65 & 0,247 \\
Belajar & Berdasarkan nilai tengah & 1,354 & 1 & 65 & 0,249 \\
& Berdasarkan nilai tengah dengan & 1,354 & 1 & 62,867 & 0,249 \\
& $\begin{array}{l}\text { mengikuti df } \\
\text { Berdasarkan pemangkasan nilai }\end{array}$ & 1,403 & 1 & 65 & 0,241 \\
& rata-rata & & & & \\
\hline
\end{tabular}

Tabel 7 Uji Homogenitas Posttest Kelas Eksperimen dan Kelas Kontrol

\begin{tabular}{clrrrr}
\hline & & $\begin{array}{c}\text { Levene } \\
\text { Statistic }\end{array}$ & df1 & df2 & Sig. \\
\hline Hasil & Berdasarkan nilai rata-rata & 11,206 & 1 & 65 & 0,001 \\
Belajar & Berdasarkan nilai tengah & 9,549 & 1 & 65 & 0,003 \\
& Berdasarkan nilai tengah dengan & 9,549 & 1 & 64,688 & 0,003 \\
& $\begin{array}{l}\text { mengikuti df } \\
\text { Berdasarkan pemangkasan nilai } \\
\text { rata-rata }\end{array}$ & 11,206 & 1 & 65 & 0,001 \\
\hline
\end{tabular}

Bedasarkan Tabel 6 dan Tabel 7, uji homogenitas menggunakan Levene Statistic pada data pretest diperoleh sig $0,247>0,05$. Hal ini menunjukkan bahwa kedua kelas memiliki varian yang homogen dengan kata lain memiliki variasi yang sama. Sedangkan, data posttest diperoleh sig $0,001<0,05$. Hal ini menunjukkan bahwa kedua kelas memiliki varian yang tidak homogen dengan kata lain memiliki varians yang berbeda.

Tabel 8 Hasil Perhitungan Standar Gain

\begin{tabular}{clcc}
\hline Statistik & Kelas & Nilai & Klasifikasi \\
\hline Standar Gain & Eksperimen & 0,499 & Sedang \\
& Kontrol & 0,303 & Sedang \\
\hline
\end{tabular}

Nilai yang diperoleh dari kedua kelas tersebut menunjukkan bahwa kedua kelas tersebut berada pada klasifikasi yang sama yaitu klasifikasi sedang. Hal ini menandakan bahwa kedua kelas tersebut diberi perhatian yang sama.

Tabel 9 Hasil Persen Pengaruh Model Pembelajaran

\begin{tabular}{ccc}
\hline Statistik & Nilai \\
\hline Rata-rata Posttest Eksperimen & 53,55 & \\
Rata-rata Posttest Kontrol & 34,12 & \\
$\%$ Pengaruh & $29,49 \%$ & \\
\hline
\end{tabular}

Pada pengujian hipotesis penelitian,hasil pengujian yang diperoleh pada hasil pretest kelas eksperimen dan kelas kontrol diperoleh hasil bahwa kedua kelas tersebut berdistribusi normal dan homogen. Sehingga, data pretest kedua kelas tersebut dilanjutkan dengan pengujian Independent Sampel $t$ Test. Pengujian Independent Sampel $t$ Test dilakukan degan bantuan Software SPSS 22 dapat dilihat hasil pengujiannya pada Tabel 10 berikut ini: 
Tabel 10 Hasil Uji Independent Sampel t Test Nilai Pretest

\begin{tabular}{|c|c|c|c|c|c|}
\hline \multicolumn{6}{|c|}{ t-test for equality of means } \\
\hline & $\mathrm{T}$ & Df & $\begin{array}{l}\text { Sig. }(2- \\
\text { tailed) }\end{array}$ & $\begin{array}{c}\text { Mean } \\
\text { difference }\end{array}$ & $\begin{array}{l}\text { Std.error } \\
\text { difference }\end{array}$ \\
\hline $\begin{array}{l}\text { Equal variances } \\
\text { assumed }\end{array}$ & 2,236 & 65 & 0,029 & 1.893 & 0,847 \\
\hline $\begin{array}{l}\text { Aqual variances not } \\
\text { assumed }\end{array}$ & 2,228 & 60,780 & 0,030 & 1.893 & 0,850 \\
\hline
\end{tabular}

Berdasarkan Tabel 10 diatas menunjukkan bahwa tidak terdapat perbedaan yang signifikan terhadap hasil belajar kognitif peserta didik sebelum diberikan perlakuan dengan penggunaan model pembelajaran yang berbeda pada kedua kelas tersebut.

Tabel 11 Hasil Uji Non Parametrik Posttest

\begin{tabular}{lr}
\hline & Hasil_Belajar \\
\hline Mann-Whitney U & 342.000 \\
Wilcoxon W & 937.000 \\
Z & -2.756 \\
Asymp.Sig.(2-tailed) & 0,006 \\
\hline
\end{tabular}

Berdasarkan hasil pengujian non parametrik yang telah dilakukan menunjukkan bahwa terdapat perbedaan yang signifikan dalam penggunaan model Inkuiri Terbimbing terhadap hasil belajar kognitif pada pokok bahasan Kelarutan dan Hasil Kali Kelarutan.

Pelaksanaan pembelajaran dengan model pembelajaran inkuiri terbimbing dimulai dengan guru mengkondisikan peserta didik terlebih dahulu dengan memberikan motivasi pada peserta didik sebelum memulai pembelajaran serta menginformasikan langkah-langkah pembelajaran yang akan berlangsung, yaitu pembelajaran akan berpusat pada peserta didik dengan mencari jawaban atas pertanyaan atau permasalahan yang telah ditentukan guru diawal pembelajaran. Peserta didik akan memecahkan pertanyaan atau permasalahan tersebut dengan melakukan praktikum sesuai dengan LKS yang dibagikan oleh guru, selain itu juga peserta didik Jurnal Komunikasi Pendidikan, vol. 1 (1) 2017, p. 59-68 diberikan pertanyaan seputar soal hitungan yang harus dikerjakan berdasarkan contoh soal yang terdapat pada buku pegangan peserta didik dengan bimbingan guru. Peserta didik menyelesaikan masalah dengan kelompok yang telah ditentukan oleh guru. Guru membentuk 6 kelompok, masing-masing kelompok terdiri dari 4-6 orang peserta didik yang ditentukan secara acak. Melalui proses diskusi kelompok ini peserta didik dapat saling bertukar pikiran, saling membantu dan berbagi ilmu dengan peserta didik yang lain. Setelah peserta didik duduk bersama kelompoknya masing-masing selanjutnya guru mengarahkan peserta didik dalam proses praktikum dengan menjelaskan proses praktikum yang terdapat pada LKS dan yang akan dilakukan pada tiap-tiap kelompok, sehingga dalam memecahkan pertanyaan atau permasalahan peserta didik dapat mencari solusi atas pertanyaan atau permasalahan tersebut. Pada saat 
proses tersebut berlangsung guru mengontrol dan membimbing peserta didik dalam kelompokkelompok tersebut.

Penerapan model pembelajaran inkuiri terbimbing ini dilakukan sebanyak empat kali sesuai dengan materi-materi yang telah dibagi. Materi-materi yang dikembangkan menjadi pertanyaan dan permasalahan yang diberikan kepada peserta didik tiap pertemuan tidaklah sama. Adapun konsep pada pertemuan pertama adalah "Faktor-faktor yang mempengaruhi kelarutan serta persamaan kesetimbangan hasil kali kelarutan (Ksp)", pada pertemuan kedua "Hubungan antara kelarutan dan hasil kali kelarutan serta pengaruh penambahan ion sejenis", "memprediksi terbentuknya endapan" pada pertemuan ketiga, dan pada pertemuan keempat "hubungan antara Ksp dan $\mathrm{pH}$ serta prinsip kegunaan kelarutan dan hasil kali kelarutan dalam kehidupan sehari-hari”.

Peserta didik akan mempresentasikan hasil diskusi kelompoknya didepan kelas, peserta didik juga akan menjelaskan jawaban yang diperoleh dari kelompoknya. Pada langkah ini peserta didik dilatih untuk berani mengungkapkan pendapatnya didepan kelas, peserta didik juga akan merasa bangga dengan kemampuan yang diperoleh setelah berani mempresentasikan hasil belajarnya selain itu peserta didik juga dilatih untuk bertanggung jawab dengan jawabannya. Proses ini berlangsung dengan arahan guru pada langkah ini guru bertindak sebagai pengarah dalam proses tersebut.

Langkah terakhir pada model pembelajaran ini adalah pembuatan kesimpulan. Kesimpulan dari proses pembelajaran berlangsung disampaikan oleh peserta didik dengan bimbingan yang diberikan oleh guru. Pada proses ini peserta didik secara aktif mengajukan dirinya untuk membuat kesimpulan apa yang telah diperoleh pada proses pembelajaran tersebut. Hal tersebut diakibatkan mulai timbulnya rasa percaya diri dan semangat dalam mengikuti pembelajaran.

Berdasarkan analisis tingkat kesukaran tes dengan subbab materi memperkirakan terbentuknya endapan berdasarkan harga Ksp merupakan indikator yang digunakan untuk menyusun soal tes pada nomor 4.Pada soal tersebut kedua kelas memiliki klasifikasi yang berbeda.Kelas eksperimen memiliki klasifikasi sedang.Sedangkan, pada kelas kontrol memiliki klasifikasi sukar. Hal tersebut disebabkan pada pelaksanaan pembelajaran peserta didik pada kelas kontrol terbiasa mengerjakan soal yang sama dengan soal-soal yang diberikan pada contoh dan latihan soal sehingga, ketika bentuk soalnya digantikan peserta didik akan kebingungan. Peserta didik pada kelas ini kurang aktif bertanya dalam proses pembelajaran. Berbeda dengan kelas eksperimen, pada kelas eksperimen peserta didik aktif dalam pembelajaran dan cukup aktif bertanya pada guru ketika proses diskusi atau presentase teman kelompok lainnya mempresentasekan jawabannya sehingga mereka lebih dapat mengantisipasi bentuk-bentuk soal yang akan diberikan oleh guru.

Selama proses pembelajaran pada kelas eksperimen berlangsung seluruh kegiatan pembelajaran melibatkan peserta didik, sehingga peserta didik tampak menunjukan keaktifan 
peserta didik dalam proses pembelajaran. Peranan guru pada proses pembelajaran inkuiri terbimbing ini hanyalah bertindak sebagai motivator, fasilitator, penanya serta pengarah. Sementara siswa sendiri yang akan terlibat aktif dalam proses pembelajaran. Motivasi yang diberikan pada peserta didik diawal pembelajaran agar peserta didik lebih semangat dan percaya diri dalam mengikuti proses pembelajaran. Fasilitas yang diberikan oleh guru berupa alat, bahan, LKS pada praktikum yang akan dilakukan peserta didik serta sebagai penunjuk jalan keluar dalam kesulitan yang dialami oleh peserta didik. Penanya pada proses pembelajaran guru akan menyadarkan peserta didik terhadap kekeliruan peserta didik melalui pertanyaan. Guru juga memimpin kegiatan siswa untuk mencapai tujuan yang diharapkan. Sehingga dalam proses presentasi tiap-tiap kelompok guru dapat mengarahkan pembicaraan peserta didik agar tidak keluar dari topik yang sedang dibahas.

Hal yang menjadi kendala dalam penerapan model pembelajaran inkuiri terbimbing ini, ialah peserta didik belum terbiasa belajar dengan model inkuiri terbimbing menyelesaikan permasalahan diberikan oleh guru.Hal ini terjadi karena peserta didik sudah terbiasa dengan model pembelajaran konvensional yang mana peserta didik terbiasa hanya mendapatkan penjelasan dari guru untuk memahami konsep materi pelajaran.Untuk mengatasi kesulitan itu guru membimbing peserta didik melalui pertanyaan-pertanyaan yang mengarahkan peserta didik dan juga membimbing dan mengarahkan peserta didik secara langsung dalam tahap-tahap
pembelajarannya.Kedua, siswa masih belum terbiasa menggunakan alat dan bahan dalam kegiatan praktikum, sehingga guru mengatasinya dengan mengarahkan dan membimbing siswa dalam kegiatan praktikum. Kendala lainnya suasana kelas menjadi ramai terutama saat proses diskusi dan hal ini dapat menganggu proses belajar dan konsentrasi peserta didik, untuk mengatasi kesulitan tersebut guru lebih ekstra mengendalikan kelas dan kegiatan pembelajaran agar diskusi dapat terarah.

Berdasarkan hasil analisis dapat diketahui bahwa perbandingan rata-rata hasil belajar kognitif peserta didik menggunakan model pembelajaran inkuiri terbimbing lebih tinggi dari pada rata-rata peserta didik yang menggunakan model pembelajaran konvensional.Hal tersebut disebabkan karena pembelajaran dengan model pembelajaran inkuiri terbimbing menuntut aktivitas peserta didik lebih meningkat.

Selama proses pembelajaran berlangsung di kelas kontrol, tidak terdapat suasana yang membangun keaktifan peserta didik untuk mengikuti proses pembelajaran. Hal ini disebabkan peserta didik beranggapan bahwa diskusi dan praktikum yang dilaksanakan merupakan diskusi kelompok biasa. Tidak adanya tanggung jawab peserta didik terhadap proses diskusi dan melakukan praktikum ini yang menjadi salah satu penyebab tidak efektifnya proses pembelajaran yang berlangsung. Tidak adanya tanggung jawab serta tidak fokusnya peserta didik dalam proses pembelajaran inilah yang mengakibatkan prestasi belajar peserta didik kurang maksimal. Selain itu, peserta didik hanya berharap dan bergantung pada guru sehingga 
proses pembelajaran yang berlangsung sangat monoton dikarenakan proses pembelajaran hanya berlangsung satu arah. Oleh karena itu hasil belajar kognitif peserta didik yang menerima pembelajaran dengan model Inkuiri Terbimbing lebih tinggi dibandingkan peserta didik yang menerima pelajaran dengan model konvensional. Hal ini dapat dilihat dari nilai yang diperoleh oleh kelas eksperimen dan kelas kontrol, diantaranya: nilai maksimal kelas eksperimen adalah 98. Sedangkan nilai maksimal kelas kontrol adalah 75 .

Penerapan model pembelajaran Inkuiri Terbimbing terhadap hasil belajar kognitif dibuktikan juga dengan menghitung besarnya pengaruh dari penerapan model pembelajaran inkuiri terbimbing tersebut. Persen pengaruh dari penerapan model pembelajaran inkuiri terbimbing terhadap hasil belajar kognitif peserta didik diperoleh dari nilai rata-rata posttest antara kelas eksperimen dengan kelas kontrol. Nilai rata-rata posttest yang diperoleh dari kelas eksperimen sebesar 53,55 dan nilai rata-rata posttest yang diperoleh dari kelas kontrol sebesar 34,12 dengan nilai maksimal yang digunakan sebessar 100. Besar persen pengaruh yang didapat sebesar $29,49 \%$.

\section{KESIMPULAN}

Berdasarkan hasil dan pembahasan dapat disimpulkan bahwa ada perbedaan yang signifikan dalam penggunaan model pembelajaran inquiry terbimbing terhadap hasil belajar kognitif peserta didik di SMA Negeri 1 Manokwari studi pada pokok bahasan Kelarutan dan Hasil Kali Kelarutan. Persentasi pengaruh yang diperoleh dari penerapan model pembelajaran inquiry terbimbing adalah sebesar $29,49 \%$

\section{DAFTAR PUSTAKA}

Sanjaya, W. Strategi Pembelajaran Berorientasi Standar Proses Pendidikan. Kencana. Jakarta. 2013.

Setiowati Hanifah, Nugroho Agung \& Agustina Widiastuti. Penerapan Model Pembelajaran Inkuiri Terbimbing (Guided Inquiry) Dilengkapi LKS Untuk Meningkatkan Aktivitas Dan Prestasi Belajar Siswa Pada Materi Pokok Kelarutan Dan Hasil Kali Kelarutan Kelas XI MIA SMA Negeri 1 Banyudono Tahun Pelajaran 2014/2015. Jurnal Pendidikan Kimia. Vol 4. No 4. 2015.

Sidin, A M. Evaluasi Pembelajaran. Makasar.Universitas Negeri Makasar. 2012.

Slameto.Belajar dan Faktor-Faktor Yang Mempengaruhi. Rineka Cipta. Jakarta. 2013.

Suardana, I K. Penilaian Portopolio dalam Pembelajaran Fisika Berbasis Inkuiri Terbimbing di SMP Negeri 2 Singaraja.Jurnal Penelitian dan Pengembangan Pendidikan.1(2).122-134. 2007.

Suprijono,A. Cooperative Learning. Yogyakarta :Pustaka Belajar. 2013.

Sudarmo, U. Kimia Untuk Sma/Ma Kelas XI.Jakarta :Erlangga. 2014.

Sukardi, Metodologi Penelitian Pendidikan. Jakarta :Bumi Aksara. 2003.

Sugiyono.Metode Penelitian Pendidikan. Bandung. Alfabeta. 2008.

Suprapto.Metodologi Penelitian Ilmu Pendidikan Dan Ilmu-Ilmu Pengetahuan Sosial. Yogyakarta: Caps. 2013.

Surjaweni,W.V. SPSS Untuk Penelitian.Yogyakarta. Pustaka Baru Press. 2014.

Syah,M. Psikologi Belajar. Jakarta: Pt Raja Grafindo Persada. 2005.

Trianto, Model - Model Pembelajaran Inovatif Berorentasi Konstruktivis, Prestasi Pustaka. Jakarta. 2011,

Umiyati N \& Haryono.Buku Siswa Kimia Untuk SMA/MA XI Peminatan Matematika dan Ilmu - Ilmu Alam. Surakarta. Mediatama. 2014.

Zaini, H. Strategi Pembelajaran Aktif Implementasi dan Kendala Di Dalam Kelas.Makalah disajikan pada seminar dan Lokakarya Nasional "Peneningkatan Kualitas Pembelajaran Melalui Aktif Learning Menuju Profesionalisme Guru.FKIP Universitas Sebelas Maret. Surakarta. 2009. 